\title{
Resistance to Common Bacterial Blight of Bean Introgressed from Phaseolus coccineus
}

\author{
M.M. Welsh ${ }^{1}$ \\ U.S. Department of Agriculture-Agricultural Research Service, Western \\ Regional Plant Introduction Station, P.O.Box46402, Pullman, WA99164-6402 \\ K.F. Grafton \\ Department of Plant Sciences, North Dakota State University, Fargo, ND 58105
}

Additional index words. Phaseolus vulgaris, disease, genetics

\begin{abstract}
Common bacterial blight, incited by Xanthomonas campestris pv. phaseoli (Smith) Dye, is a major bacterial disease of dry bean (Phaseolus vulgaris L.). Resistance to common bacterial blight has been identified in other Phaseolus species and resistance genes have been introgressed into $P$. vulgaris. The objective of this study was to characterize in dry bean the inheritance pattern of common bacterial blight-resistance genes derived from $\boldsymbol{P}$. coccineus. Two common, bacterial blight-susceptible, dry bean cultivars were crossed with different common, bacterial blight-resistant dry bean lines with resistance derived from $P$. coccineus. $F_{2}$ progeny were inoculated with Xanthomonas campestris pv. phaseoli strain F19-W and were scored for disease reaction. The ratio of resistant to susceptible plants for $F_{2}$ populations did not differ significantly from a 1 resistant : 3 susceptible ratio. The $F_{3}$ segregation was obtained for only one cross and did not differ significantly from a 1 resistant : 2 heterozygous : 1 susceptible ratio, suggesting that the resistance introgressed from $P$. coccineus into dry bean was controlled by one recessive gene. Additionally, the range of symptom expression within the susceptible class provided evidence of other genes modifying the expression of resistance.
\end{abstract}

Common bacterial blight $(\mathrm{CBB})$ is one of the major bacterial diseases of common bean (Saettler, 1991). Planting disease-free seed (certified seed) is the primary cultural control measure (Coyne and Schuster, 1980), but genetic resistance would provide the best solution (Singh and Muñoz, 1999; Zapata et al., 1985). Limited genetic variation for resistance to $\mathrm{CBB}$ in $P$. vulgaris underscores the need for other sources of resistance (van Schoonhoven and Voysest, 1991). Common bacterial blight resistance has been identified in other Phaseolus species and has been introgressed into P. vulgaris (Burkholder and Bullard, 1946; Coyne et al., 1965; Freytag et al., 1982; Miklas et al., 1994; Park and Dhanvantari, 1986; Schuster, 1955).

A greater level of resistance to $\mathrm{CBB}$ has been noted in some $P$. coccineus $\mathrm{L}$. accessions (Coyne and Schuster, 1973; Coyne et al., 1963; Freytag et al., 1982; Singh and Muñoz, 1999). Previous genetic analyses have suggested a quantitative model of inheritance (Park and Dhanvantari, 1986; Yu et al., 1998), but a full

Received for publication 5 June 2000 . Accepted for publication 12 Oct. 2000. We thank P.N. Miklas for providing the CBB-resistant seed. J.R. Venette provided Xanthomonas campestris pv. phaseoli strain F19-W, and Robin Lamppa prepared and quantified the inoculum. The cost of publishing this paper was defrayed in part by the payment of page charges. Under postal regulations, this paper therefore must be hereby marked advertisement solely to indicate this fact.

${ }^{1}$ To whom reprint requests should be addressed. Email address: mmwelsh@wsu.edu characterization of the inheritance of $\mathrm{CBB}$ resistance derived from $P$. coccineus has not been completed. Therefore, the objective of this study was to characterize the inheritance pattern of CBB-resistance genes derived from $P$. coccineus.

\section{Materials and Methods}

All disease screening was conducted in greenhouses at Fargo, N.Dak. Two separate populations were produced: 'Midland' (CBBsusceptible navy bean) X '92BG-191' [population\#1] and 'Aztec' (CBB-susceptible pinto bean) X '92BG-139' [population \#2]. '92BG139 ' is a sister line to 'TARS VCI-4B' (a multiple disease-resistant, small-seeded pinto dry bean from a recurrent, interspecific cross selection program that included $P$. coccineus accessions PI311950 and PI311977) (Miklas, et al., 1994). '92BG-191' was produced by similar breeding methods using the $P$. coccine us accessions PI 311950 and PI 273667 (P. Miklas, personal communication, 1997).

$\mathrm{F}_{2}$ plants of populations \#1 and \#2, 181 and 129 plants, respectively, were inoculated with Xanthomonas campestris pv. phaseoli. Two $\mathrm{F}_{2}$ seeds per 15 -cm-diameter pot, including 10 pots of each parental line as a control, were sown in Sunshine Mix medium (SunGro Horticulture, Bellevue, Wash.), augmented with 7.1 g perpotOsmocotefertilizer(Scott's, Marysville, Ohio) $(14 \mathrm{~N}-7 \mathrm{P}-7 \mathrm{~K})$. The greenhouse was maintained at a 14- to 16 -h photoperiod using natural light supplemented by high-pressure sodium lamps $\left(1300 \mu \mathrm{mol} \cdot \mathrm{m}^{-2} \cdot \mathrm{s}^{-1}\right)$; greenhouse temperatures ranged from 22 to $27{ }^{\circ} \mathrm{C}$ and relative humidity from $20 \%$ to $65 \%$. Before inoculation, plants were watered and placed in an inoculation chamber at $100 \%$ relative humidity for 2 to $3 \mathrm{~h}$. The middle leaflet of the fully expanded, fourth trifoliate leaf of each $\mathrm{F}_{2}$ plant was inoculated by the multiple puncture method(Coyne et al., 1965) at the preflowering stage. After $30 \mathrm{~h}$ the plants were returned to the greenhouse. Disease reaction was evaluated 7 , 14 , and $21 \mathrm{~d}$ after inoculation and scored from 1 to 5 , based on a previous inoculation study (Welsh, 1997). Susceptible parents scored in a range of 4-5, and resistant parents had scores of $1-2$. Sixteen seeds (Hanson, 1959) of $122 \mathrm{~F}_{3}$ families in population \#1 were evaluated for resistance. The planting medium, fertilizer regime, and greenhouse conditions, and the incubation, evaluation, and scoring procedures were similar to those used for the $\mathrm{F}_{2}$ populations. However, for $\mathrm{F}_{3}$ plants, the fully expanded unifoliate leaf was inoculated on the underside by tissue infusion with a hypodermic syringe (Adams et al., 1989). A previous study indicated similar response when using either the multiple puncture or tissue infusion method (Welsh, 1997). A susceptible $\mathrm{F}_{3}$ family contained individuals with scores ranging from 3 to 5 and with symptom expression increasing over time. Resistant families contained individuals with scores ranging from 1 to 2 and symptom expression did not increase over time. Heterozygous families contained individuals with scores ranging from 1 to 5 , and symptom expression of the plants scoring $>2$ increased over time. Analysis of the data by the chi square test of goodness of fit and heterogeneity at the $P<0.05$ level of significance was performed.

X. campestris pv. phaseoli strain F19-W (J. Venette, Dept. of Plant Pathology, North Dakota State Univ.) was grown on yeast-dextrose-carbonate growth media for 24 to $48 \mathrm{~h}$ at $27^{\circ} \mathrm{C}$. Bacteria were scraped from the surface of the medium and suspended in sterile distilled water to a concentration of $1 \times 10^{9}$ cells/ $\mathrm{mL}$. Concentration was determined by absorption at OD 660 and compared with a previously established standard growth curve, relating cell number to absorbency. The inoculum was prepared by diluting this suspension with sterile distilled water to $1 \times 10^{7}$ cells/ $\mathrm{mL}$.

\section{Results and Discussion}

Resistance to $\mathrm{CBB}$, as represented by scores of 1 and 2, was expressed as no visible symptom development, or the leaf tissue developed a narrow, nonexpanding, chlorotic band around the inoculation site. Parents '92BG-191' and '92BG-139' had scores of 1-2. In the susceptible reaction, as represented by scores of $3-5$, chlorosis and water soaking were present, and necrosis developed and expanded in some cases until the entire leaflet was dead or had abscised from the plant. Parents 'Midland' and 'Aztec' had scores of 4-5.

The ratio of resistant to susceptible $\mathrm{F}_{2}$ plants did not differ significantly from a 1 resistant : 3 susceptible ratio, and the ratio of resistant to 
susceptible $\mathrm{F}_{3}$ families did not differ significantly from a 1 resistant : 2 heterozygous : 1 susceptible ratio (Table 1), as expected if resistance is controlled by one recessive gene.

To prevent loss of desired characters from the $P$. vulgaris genome, transfer of a small piece of the $P$. coccineus genome containing the gene of interest into the $P$. vulgaris genome would be most desirable. The resistant parents used were advanced lines derived from $P$. vulgaris $\times P$. coccineus crosses; they expressed good CBB resistance in field tests in Puerto Rico (P. Miklas, personal communication, 1992), yet possessed morphological traits associated with $P$. vulgaris. A small introgression from $P$. coccineus could explain the presence of resistance in the material used in this study.

The recessive resistance gene from $P$ coccineus already incorporated into $P$. vulgaris germplasm lines ' 92 BG-191' and '92BG-139' probably represents a potential source of CBB resistance not previously utilized in breeding programs; it confers a high level of resistance, indicating a major gene.

The level of resistance, conferred by a recessive gene, expressed in this experiment appeared to be similar to that conferred by gene(s) from $P$. acutifolius A. Gray, but the latter have been described as dominant (Michaels, 1992). Resistant parental lines in this experiment have similar sources for the $\mathrm{CBB}$ resistance, sharing one $P$. coccineus ancestor. Tests for allelism could provide clarification on these points.

The range of symptom expressions within the susceptible classes of $\mathrm{F}_{2}$ plants and $\mathrm{F}_{3}$ families showed a progression of reactions: chlorosis, water-soaking, tissue collapse, and necrosis expanding at slow rates out from the inoculation site through a more rapid development of all symptoms combined with eventual leaflet death. Some level of quantitative resistance, e.g., modifier genes, might explain this

Table 1. Segregation ratios in dry bean for resistance to common bacterial blight strain F19-W introgressed from $P$. coccineus.

\begin{tabular}{lcccccc}
\hline \hline $\begin{array}{l}\text { Segregating } \\
\text { population }\end{array}$ & Resistant & Heterozygous & Susceptible & Ratio & $\chi^{2}$ & $P$ \\
\hline $\begin{array}{l}\text { Midland/92 BG 191 F } 2 \\
\text { Aztec/92 BG 139 F }\end{array}$ & 38 & --- & 143 & $1: 3$ & 1.55 & 0.2131 \\
$\begin{array}{l}\text { Midland/92 BG 191 } \\
F_{3} \text { families }\end{array}$ & 24 & --- & 105 & $1: 3$ & 2.81 & 0.0937 \\
\hline
\end{tabular}

result. Segregation within both $\mathrm{F}_{2}$ populations showed bias toward the susceptible parent, but heterozygotic influence was indicated in $\mathrm{F}_{3}$ families. Further consideration of these observations could help explain such discrepancies, and add to the understanding and value of this source of resistance.

\section{Literature Cited}

Adams, M.W., J.D. Kelly, and A.W. Saettler. 1989 A gene for resistance to common blight (Xanthomonas campestris pv. phaseoli). Annu. Rpt. Bean Imp. Coop. 32:73-74.

Burkholder, W.H. and E.T. Bullard. 1946. Varietal susceptibility of beans to X.phaseoli var. fuscans. Plant Dis. Rpt. 30:446-448.

Coyne, D.P. and M.L. Schuster. 1973. Phaseolus germplasm tolerant to common blight bacterium (Xanthomonas phaseoli). Plant Dis. Rpt. 57:111-114.

Coyne, D.P. and M.L. Schuster. 1980. Bacterial disease of legumes: Breeding and resistance, $p$. 225-233. In: R.J. Summerfield and A.H. Bunting (eds.). Advances in legume science. Royal Bot. Gardens, Kew, England.

Coyne, D.P., M.L. Schuster, and S. Al-Yasiri. 1963. Reaction studies of bean species and varieties to common blight and bacterial wilt. Plant Dis. Rpt. 47:534-537.

Coyne, D.P., M.L. Schuster, and L. Harris. 1965. Inheritance, heritability, and response to selection for common blight (Xanthomonas phaseoli) tolerance in Phaseolus vulgaris field bean crosses. J. Amer. Soc. Hort. Sci. 86:373-379.

Freytag, G.F., M.J. Bassett, and M. Zapata. 1982. Registration of XR-235-1-1 bean germplasm. Crop Sci. 22:1268-1269.
Hanson, W.D. 959. Minimum size for the planning of genetic experiments. Agron. J. 51:711.

Michaels, T.E. 1992. Genetic control of common blight resistance in lines derived from $P$. vulgaris/P. acutifolius crosses. Annu. Rpt. Bean Imp. Coop. 35:40-41.

Miklas, P.N., J.S. Beaver, K.F. Grafton, and G.F. Freytag. 1994. Registration of TARS VCI-4B multiple disease resistant dry bean germplasm. Crop Sci. 34:1415.

Park, S.J. and B.N. Dhanvantari. 1986. Transfer of common blight (Xanthomonas campestris pv. phaseoli) resistance from Phaseolus coccineus Lam. to $P$. vulgaris $\mathrm{L}$. through interspecific hybridization. Can. J. Plant Sci. 67:685-695.

Saettler, A.W. 1991. Diseases caused by bacteria: CBB. p. 29-30. In: R. Hall (ed.). Compendium of bean diseases. APS Press, St. Paul, Minn.

Schuster, M.L. 1955. A method for testing resistance of beans to bacterial blights. Phytopathology 45:519-520.

Singh, S.P. and C.G. Muñoz. 1999. Resistance to common bacterial blight among Phaseolus species and common bean improvement. Crop Sci. 39:80-89.

van Schoonhoven, A. and O. Voysest. 1991. Common beans: Research for crop improvement. Centro Intel de Agr. Tropical, Cali, Colombia.

Welsh, M.M. 1997. Identifying genes for resistance to common bacterial blight of bean. PhD Diss., Dept. of Plant Sciences, North Dakota State Univ., Fargo.

Yu,Z.H., R.E. Stall, and C.E. Vallejos. 1998. Detection of genes for resistance to common bacterial blight of beans. Crop Sci. 38:1290-1296.

Zapata, M., G.F. Freytag, and R.F. Wilkinson. 1985. Evaluation for bacterial blight resistance in beans. Phytopathology 75:1032-1039. 